
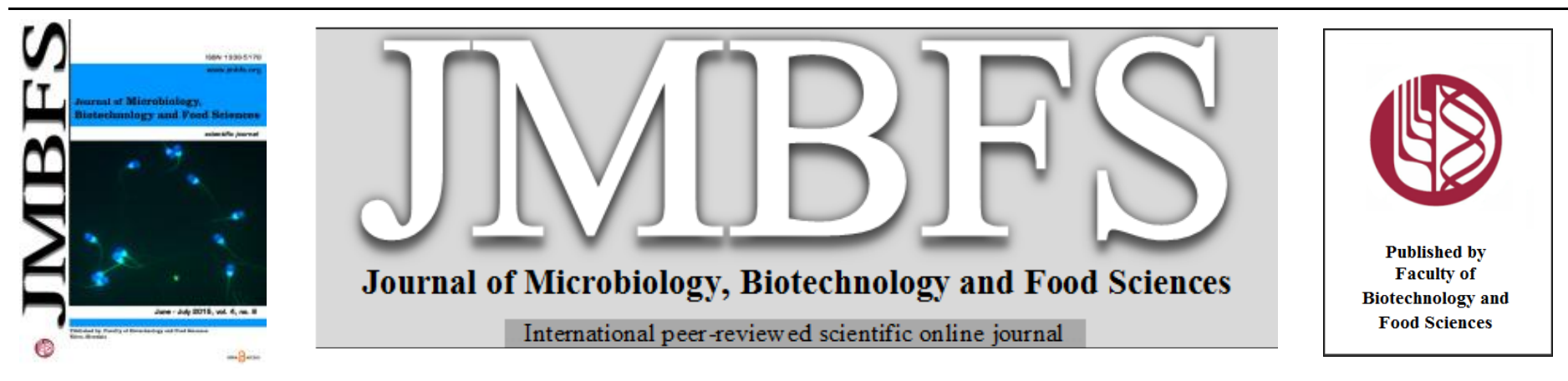

\title{
UNDERSTANDING SOCIAL INTERACTIONS OF MICROBES USING TRANSCRIPTOMICS : A CODICIL
}

\section{Prem Saran Tirumalai*}

Address(es): Prem Saran Tirumalai,

Dayalbagh Educational Institute, Faculty of Science, Department of Zoology, Dayalbagh, Agra - 282005,Uttar Pradesh, +919410421149.

*Corresponding author: premtsaran@gmail.com

doi: 10.15414/jmbfs.2015.4.6.491-495

\section{ARTICLE INFO}

Received 4. 9. 2014

Revised 25. 3. 2015

Accepted 1. 4. 2015

Published 1.6. 2015

Review

open $\mathcal{O}$ access

\section{INTRODUCTION}

The realm of microbes; the deeper we dive, the farther and wider the bottom is, it appears. Microbiology has been contributing significantly towards understanding biology in general, and prodigious revelations have been made in biology at molecular level. Many of the discoveries made through microorganisms have been the center stage in the development of many genetic-engineering technologies (Zimmer, 2009). Although, it may appear that biological science today has reached the summit, research reports continue to confound our ideas of microbial life and here we discuss the sociobiology of microbes in particular, the least dealt and the most baffling of all and why transcriptomics is of relevance in this context.

Sociobiology of microbes, does that matter?

For more than a century, ever since the advent of the science of microbiology, microbiologists have been engaged in understanding microbes as pure cultures In fact, the very basis of classical microbiological methods rests on efficient pure culture techniques. In the pursuit of understanding pure cultures, it was long forgotten that microbes indeed lead a social life and that they seldom exist as pure cultures in natural environment. However, reports in the past decade have given us to believe that the purview of sociobiology of microbes does matter, and it is of relevance.

Like most species, almost everything that a microbe does, has social implications. Even the very basic aspect of life, such as reproduction, could deprive a neighbor of its resources and therefore bring about a conflict (MacLean, 2006). Besides, microbes also secrete in abundance, metabolites, toxins (Pettit, 2009), and even extracellular DNA (Johnson et al. 2013), all of which can have an affect on their social neighbours. In this regard, it is of relevance and a necessity to rekindle a view point of ecology, which states that 'the behavior of most organisms living in close proximity will be governed by competition or cooperation' (Alexander, 1974). It is understandable that in such social communities, microbes are bound to tradeoff with other community denizens ( Crespi, 2001; Schink, 2002; Velicer, 2003; Mitri et al. 2011). Considering this to be an ecological gospel, it should be agreed upon that such social conditions, not only influence the logarithmic growth but also provide ample opportunities for metabolic interactions within the community. The interactions can and has been radically altering the biochemical phenotypes and or the morphological characteristics of the participating strains, also leading to social evolution (Foster, 2005; Boyle $\boldsymbol{e}$ al. 2013). This very logical understanding makes it agreeable that the behaviora pattern of a socially living microbe, which is the naturally occurring state of most microbes, is bound to be divergent to the lab grown pure cultures. And it is also understandable that behavioral pattern, be it with respect to metabolism, secretions, the multiplication rate, and the fundamental process of gene expression that governs all of it, is likely to vary. Thus the reasons to discuss transcriptomics with relevance to social psyche are well substantiated and require thorough review and investigation.

\section{Gene Expression with Relevance to Microbial Social Interactions}

Discussions on sociobiology of microbes have gained importance in the recent past. Research findings and discussions in this stream have overlapping implications with varied interest, from evolution, ecology to systems science. Reports on varied forms and levels of social interactions have come to light However, the most intriguing and with immediate interests, in relation to gene expression studies in sociobiology are on Quorum Sensing and Co-existence, Metabolic Synergism in microbial communities and Sociobiology with relevance to pathogenicity and virulence. In order to demonstrate the magnitude of the necessity for gene expression studies in sociobiology, we review and discuss these aspects in brief.

\section{Metabolic Synergism in Microbial communities}

Regardless of the locale, a microbial niche is a package of multiple species and strains, wherein interactions govern co-existence and cells compete, co-operate, conflict and if need be, coerce and cheat. This influences the fundamental aspects of microbial progression in a mixed culture community. When in mixed culture, the affiliating strains compete for common resource. The competition may arise not only between different species, but also between strains of the same species The competition naturally mediates a situation of either co-operation or conflict and depending on the nature and properties of the competing species, the relationship is defined. In such state of competition where in, the competing affiliates share common resources, conflict is evident (Rainey and Rainey, 2003). The sharing becomes easier and clear with resources such as carbon and oxygen (Kreft, 2004; Wintermute and Silver, 2010a). These resources due to its potential role in growth, when shared, obviously lead to conflict. (Ratnieks et al. 2006). For instance, in mixed culture, under conditions of oxygen crunch, microbes have the ability to shunt from aerobic respiration to fermentation. (Pfeiffer et al. 2001; Frick and Schuster, 2003; Pfeiffer and Bonhoeffer, 2004; Pfeiffer and Schuster, 2005; Novak et al. 2006). While respiration, owing to efficient resource management, is thought to be a cooperative strategy, fermentation on the other hand in contrast, is observed as a competitive strategy (Pfeiffer et al. 2001). The phenomenon of shift in the metabolic pathways by microbes in mixed culture therefore, has also brought to focus, the psyche of the competing and co-operating microbes in mixed cultures. 
Further, from earlier mixed culture studies (Christensenet al. 2002; Hansen $e$ al. 2007; Hibbing et al. 2009) it has been possible to extrapolate that metabolic commensalism exists between species in mixed microbial communities and that the cultures in mixed community, exhibit natural metabolic synergism and they interact (Pelz et al. 1999; Bull and Harcombe, 2009; Wintermute and Silver 2010b). These interacting partners share metabolites, such as hydrogen (Hillesland and Stahl 2010), acetate (Rozen et al. 2009), amino acids (Shou et al. 2007), fixed nitrogen (Kim et al. 2008) or glucose (Kim et al. 2008; Gore $\boldsymbol{e}$ al. 2009). These sharing features within a community, undoubtedly involves complex molecular mechanism, which at present is an arena, unexplored.

\section{Quorum Sensing and Co-existence}

Quorum sensing is machinery for cell-to-cell communication that is exhibited by group living microbes. Through cell-to-cell communication, each cell has the ability to sense the density of neighbours in a community and quorum sensing therefore has a pivotal role in colonization (Miller and Bassler, 2001; Rutherford and Bassler, 2012) and biofilm formation (Parsek and Greenberg, 2005; Moons et al. 2006; Waters et al. 2008; O'Loughlin et al. 2013). Besides communication, quorum sensing is also known to control diversified biological functions such as spore formation (LaRossa et al. 1983; Magnuson et al. 1994; Solomon et al. 1995; Solomon et al. 1996; Steiner et al. 2012), cell differentiation (Hornby et al. 2001;Hogan et al. 2004), uptake and exchange of genetic material (Duffin and Seifert, 2010; Antonova and Hammer, 2011; Suckow et al. 2011; Seitz and Bolkesch, 2013) and toxin production (Schelin $e$ al. 2011; Thoendel et al. 2011). In a population of Staphyloccus aureus, for instance, secretion of exogenous toxin occurs only in a state of high population density which is regulated by the Agr signal transduction system, a quorum sensing system (Thoendel et al. 2011).

Microbial colony or a community, as discussed, may comprise of multiple species, and this prompts us to extrapolate that quorum sensing also mediates communication between divergent species. Autoinducer-2 (AI-2), a quorum sensing molecule, produced by diverse set of species that has been inferred to have widespread interspecies communication (Federle and Bassler, 2003) is a convincing evidence for this inference. It has also been reported that quorum sensing in a mixed population could also affect the synthesis and secretion of specific proteins of divergent species (Egland et al. 2004; Xavier and Bassler, 2005; Keller and Surette, 2006; Sandoz et al. 2007).

Quorum sensing with such diverse role, is regulated by gene expression. Although different quorum sensing systems have been identified and studied, the network of regulatory mechanisms that aids in intra and interspecies interactions remain to be investigated and the expression pattern of these communicating molecules unearthed.

\section{Microbial Sociobiology with reference to Pathogenicity and Virulence}

Pathogenicity and Virulence, the qualities that describe the ability of infectious agents, owing to the magnitude of their role in infection; have been the major target science of study on pathogenic microbes. These qualities of microbes are governed by the expression of specific genes, which in turn is regulated. Although the mechanism of virulence and pathogenicity is well reported and compiled, till recently, it was only in the pure culture state that most pathogens had been studied. In the cases of infections, it is not the infectious agent alone that makes an entry into a host, infectious agent is but one among the plethora of the host intruders. In most cases of microbial intrusion, depending on the source of infection, a consortium of microbes gain entry into the host and the potent of them all establishes as the predominant infectious agent. In fact in some cases it is due to the entry as consortia that pathogenicity is initiated (Chao et al. 2000; Brown et al. 2002; Brockhurst et al. 2003; Schjorring and Koela, 2003; Thomas et al. 2003; Choisy and Roode, 2010; Ben-Ami et al. 2011). For instance, pathogenicity is expressed by Clostridium tetani only when the coinhabiting microbial consortia members cause an anoxygenic state leading to necrosis at the site of infection. And it is this condition of necrosis that triggers the release of the exotoxins by C.tetani (Campbell $\boldsymbol{e t}$ al. 2009). As early as the 1980's researchers had already reported that it is only in a group that the state of bacteremia thrives to cause the characteristic clinical symptoms. Vught et al (1986) reported that Bacteriodes fragilis and B.vulgatus both are required for abscess formation by Escherichia coli in mice. Similarly, co-infection of honeybees jointly by Ascosphaera apis and A.atra increased the mortaility rate of the bees (Vojvodic et al. 2012). These evidences indicate that co-infections by multiple species may increase the degree of illness and its effects and therefore the need for understanding the pathogenicity of a microbe in mixed population is significant. On the other hand the suppressing effect on virulence and pathogenicity of an infectious agent in a mixed population have also been reported. For instance, the effect of Lactic Acid Bacilli (LAB) in a mixed population with Staphylococcus aureus has been rigorously studied, giving rise to the findings that LAB, Lactococcus lactis namely, impairs the expression of virulence by S.aureus in mixed culture (Alomar et al. 2008; Charlier et al. 2008; Charlier et al. 2009; Even et al. 2009). Likewise it has also been reported that the virulence of Listeria monocytogenes via the expression of the prfA, a virulence regulator gene, is lowered in the presence of Bacillus subtilis (Tirumalai and Prakash, 2012a). These study have also involved the use microarray technology to investigate the transcriptomic response of apathogenic strainto the presence of a competing strain (Even et al. 2009; Tirumalai and Prakash, 2012b). Researchers are now compelled to admit that the expressions, genotypic and therefore phenotypic, of a microbial species are different in a social community. And this difference depending on the relatedness of different species in a niche can even alter the expression of Virulence and Antibiotic Resistance (Foster, 2005). Microarray and other high throughput technologies for studies on transcriptomic behavioural pattern in a social community have been put to use though, given the magnitude of the implications of gene expression and its regulations in social life of microbes, their applications seems very meager.

\section{Transcriptomics and Microbial Community Analysis}

\section{Application of High Throughput Technology}

The ultimate object of microbial ecology is to elucidate the governing factors that facilitate a microbial community to exist, in the form they do, and this could be achieved by examining the interactions within the community. The enormous microbial biocomplexity with a multitude of highly complex interactions between different micro-organisms can be understood only using molecular methods. Understanding gene expression in a mixed community therefore came to be an object in sociobiology (Allen and Banfield, 2005). Although various gene probes made it possible for studies on species-specific genes in microbial mixed communities, microarray technology radically revolutionized the ability to simultaneously study hundreds or thousands of genes at a time (Schena $\boldsymbol{e t}$ al. 1995). Majority of prokaryotic microarray studies, however, have been used to study the genome or transcriptome of a single organism and therefore for a brief period, was limited from application in understanding the complex microbial ecosystems (Dennis et al. 2003). However, owing to the enormity of the implications of gene expression studies in microbial ecology, several types of microarrays were developed and successfully applied to microbial ecology research. Phylogenetic Oligonucleotide arrays (POAs), Functional Gene Arrays (FGAs), Community Genome Arrays (CGAs), Metagenomic Arrays (MGA) and Whole Genome Open Reading Frame Arrays (WGA) are to name a few, each of which have been reviewed earlier, in context to microbial ecology research (Zhou, 2003; Gentry et al. 2006).

Studies involving microarray technology in microbial community analysis have given interesting revelations about gene expression patterns of strains in mixed cultures that are divergent to its pure culture state. Transcriptomics using DNA Microarrays proved to be effective in studies, such as the expression of 2,4dichlorophenoxyacetic acid catabolic genes and the regulation of resin acid degradative genes by Ralstonia eutropha both in mixed microbial communities of industrial effluents (Dennis et al. 2003.). Expression pattern of the whole transcriptome of Listeria monocytogenes in mixed culture broth and biofilm both in the presence of Bacillus subtilis has been elucidated using microarrays (data accessible at NCBI GEO database (Edgar $\boldsymbol{e t}$ al.2002), accession GSE27936) and the differential expressions of virulence and antibiotic resistance genes in mixed culture have been reported (Tirumalai and Prakash, 2012a; Tirumalai and Prakash, 2012b). All such research explorations also drive our interests to Metagenomics. High-throughput microarray technology has been used for studies of complex microbial communities in various environments and for studies on the diversity functions of genes and gene expressions (Zhou, 2003; Bodrossy and Sessitsch, 2004). Besides microarray based biochips have been developed specifically for screening biogeochemical cycles in the name of 'GeoChips' (He et al. 2007; Wang et al. 2009; Van Nostrand et al. 2009) and the 'HITchip' (Stojanović et al. 2009) 'HuGChip' (Tottey et al. 2013) for determining the microbial diversity of human gut. Although there have also been studies using microarrays for understanding metagenomics, with reference to identification of novel genes or proteins (Streit and Schmitz, 2004; Deutschbauer et al. 2006) and identification of uncultivable microbes in microbial niches (Wu et al. 2001; Sebat et al. 2003; Tottey et al. 2013), considering the countless natural microbial niches and the inter and intra-species community interactions that happen, the research focus and reports on metatranscriptomics is negligible.

Microarrays with a decade long history of applications in microbial ecology is gradually being superseded by the Next Generation Sequencing (NGS) technology (Ledford, 2008). As compared to microarrays, NGS is more efficient in parallel sequencing of large numbers of DNA fragments, besides being rapid and cost effective (Roh et al. 2010). Among the different NGS platforms, the pyrosequencing approach is most suited for microbial ecology studies and has been widely used for the purpose (Angly et al. 2006; Brown $\boldsymbol{e t}$ al. 2009). NGS pyrosequencing approach holds a better stand to microarrays, for applications in microbial ecology mainly because it reduces issues pertaining to specificity inherent to microarrays in microbial ecological studies (Roh et al. 2010). 


\section{DISCUSSION}

\section{Codicil}

Sociobiology of microbes has traversed quite a few miles in the last decade and has gathered moss and the prejudiced, misguided opinion that single-celled organisms are asocial, seems to have lost ground. The plethora of reports on microbial interactions, within mixed cultures in particular, brings an intriguing new standpoint. Can we hope to understand gene expression that underlie the complex network of social behavior ? Given this discernment we could anticipate that the expression of gene transcripts in socially living states of microbes is likely to be variable to their well-studied pure culture equivalents. Researchers believe that understanding the social sophistication in microbes can also open new vistas to evolutionary paths and ecological diversities (Székely $\boldsymbol{e t}$ al. 2010) Gene expression studies or transcriptomics therefore, could yield perplexing data on the behavioral pattern concerning various aspects of social existence, from growth rate to competition, co-operation or metabolic interaction between group living strains. Further, analysis of gene expression patterns within a microbia community will allow us to tease out the impact of various biotic and abiotic factors that significantly impact the regulation of metabolic functions. A complete understanding of microbial metabolism is therefore warranted. And this would extend from the properties of individual strains in pure culture to the combinatorial interactions supported by complex communities.

Although the viewpoint of sociobiology from where it stands today, appears to have far-fetching horizon with bewildering complexity, the advancements in the field of transcriptomics, can be envisaged to minuscule the lofty objects of microbial sociobiology in the years to come.

Acknowledgments: The author is thankful to the Science and Engineering Research Board of the Department of Science and Technology, Government of India for their support. The author would also like to acknowledge the administrations of the Dayalbagh Educational Institute.

\section{REFERENCES}

ALEXANDER, RD. 1974. The evolution of social behavior. Annu Rev Ecol Syst .5:325-383.http://dx.doi.org/10.1146/annurev.es.05.110174.001545

ALLEN, EE., BANFIELD, JF. 2005. Community genomics in microbial ecology and evolution. Nature Reviews Microbiology. 3(6): 489498.http://dx.doi.org/10.1038/nrmicro1157

ALOMAR, J., LOUBIERE, P., DELBES, C., NOUAILlE, S., MONTEL, MC.2008 Effect of Lactococcus garvieae, Lactococcus lactis and Enterococcus faecalis on the behaviour of Staphylococcus aureus in microfiltered milk. Food microbiology. 25(3): 502-508.http://dx.doi.org/10.1016/j.fm.2008.01.005

ANGLY, FE., FELTS, B., BREITBART, M., SALAMON, P., EDWARDS, RA. CARLSON, C., ROHWER, F. 2006. The marine viromes of four oceanic regions. $P \operatorname{LoS}$

e368.http://dx.doi.org/10.1371/journal.pbio.0040368

ANTONOVA, ES., HAMMER, BK. 2011. Quorum- sensing autoinducer molecules produced by members of a multispecies biofilm promote horizontal gene transfer to Vibrio cholerae. FEMS microbiology letters. 322(1): 68 76.http://dx.doi.org/10.1111/j.1574-6968.2011.02328.x

BEN- AMI, F., RIGAUD, T., EBERT, D. 2011. The expression of virulence during double infections by different parasites with conflicting host exploitation and transmission strategies. Journal of Evolutionary Biology. 24(6): 13071316.http://dx.doi.org/10.1111/j.1420-9101.2011.02264.x

BODROSSY, L., SESSITSCH, A. 2004. Oligonucleotide microarrays in microbial diagnostics. Current opinion in microbiology.7(3): 245 254.http://dx.doi.org/10.1016/j.mib.2004.04.005

BOYLE, KE., HEILMANN, S VAN., DITMARSCH, D., XAVIER, JB. 2013 Exploiting social evolution in biofilms. Current opinion in microbiology. 16:207-212.http://dx.doi.org/10.1016/j.mib.2013.01.003

BROCKHURST, MA., MORGAN, AD., RAINEY, PB., BUCKLING, A. 2003 Population mixing accelerates coevolution. Ecology Letters .6(11): 975 979.http://dx.doi.org/10.1046/j.1461-0248.2003.00531.x

BROWN, MV., PHILIP, GK., BUNGE, JA., SMITH, MC., BISSETT, A., LAURO, FM., DONACHIE, SP. 2009. Microbial community structure in the North Pacific ocean. The ISME journal.3(12): 1374 1386.http://dx.doi.org/10.1038/ismej.2009.86

BROWN, SP., HOCHBERG, ME., GRENFELL, BT. 2002. Does multiple infection select for raised virulence?. Trends in microbiology.10(9): 401405.http://dx.doi.org/10.1016/S0966-842X(02)02413-7

BULL, JJ., HARCOMBE, WR. 2009. Population dynamics constrain the cooperative evolution of cross-feeding. PLoS one. 4(1): e4115.http://dx.doi.org/10.1371/journal.pone.0004115

CAMPBELL, JI., YEN, LTM., LOAN, HT., DIEP, TS., NGA, TTT., HOANG, NVM., BAKER, S. 2009. Microbiologic characterization and antimicrobial susceptibility of Clostridium tetani isolated from wounds of patients with clinically diagnosed tetanus. The American journal of tropical medicine and hygiene. 80(5): 827-831.

CHAO, L., HANLEY, KA., BURCH, CL., DAHLBERG, C., TURNER, PE 2000. Kin selection and parasite evolution: higher and lower virulence with hard and soft selection. Quarterly Review of Biology. 261 275.http://dx.doi.org/10.1086/393499

CHARLIER, C., CRETENET, M., EVEN, S., LE LOIR, Y. 2009. Interactions between Staphylococcus aureus and lactic acid bacteria: An old story with new perspectives. International journal of food microbiology.131(1): 3039.http://dx.doi.org/10.1016/j.ijfoodmicro.2008.06.032

CHARLIER, C., EVEN, S., GAUTIER, M., LE LOIR, Y. 2008. Acidification is not involved in the early inhibition of Staphylococcus aureus growth by Lactococcus lactis in milk. International Dairy Journal.18(2): 197 203.http://dx.doi.org/10.1016/j.idairyj.2007.03.015

CHOISY, M, DE., ROODE, JC. 2010. Mixed infections and the evolution of virulence: effects of resource competition, parasite plasticity, and impaired host immunity. The American

E118.http://dx.doi.org/10.1086/651587

CHRISTENSEN, BB., HAAGENSEN, JA., HEYDORN, A., MOLIN, S. 2002 Metabolic commensalism and competition in a two-species microbia consortium. Applied and Environmental Microbiology.68(5): 2495 2502.http://dx.doi.org/10.1128/AEM.68.5.2495-2502.2002

CRESPI, BJ. 2001. The evolution of social behavior in microorganisms. Trends in Ecology and Evolution. 16(4): 178-183.http://dx.doi.org/10.1016/S01695347(01)02115-2

DENNIS, P., EDWARDS, EA., LISS, SN., FULTHORPE, R. 2003. Monitoring gene expression in mixed microbial communities by using DNA microarrays.Applied and environmental microbiology.69(2): 769 778.http://dx.doi.org/10.1128/AEM.69.2.769-778.2003

DEUTSCHBAUER, AM., CHIVIAN, D., ARKIN, AP. 2006. Genomics for environmental microbiology. Current opinion in biotechnology. 17(3): 229 235.http://dx.doi.org/10.1016/j.copbio.2006.04.003

DUFFIN, PM., SEIFERT, HS. 2010. DNA uptake sequence-mediated enhancement of transformation in Neisseria gonorrhoeae is strain dependent Journal of bacteriology. 192(17): 4436-4444.http://dx.doi.org/10.1128/JB.0044210

EDGAR, R., DOMRACHEV, M., LASH, AE. 2002. Gene Expression Omnibus: NCBI gene expression and hybridization array data repository. Nucleic acids research.30(1):207-210.http://dx.doi.org/10.1093/nar/30.1.207

EGLAND, PG., PALMER, RJ., KOLENBRANDER, PE. 2004. Interspecies communication in Streptococcus gordonii-Veillonella atypica biofilms: signaling in flow conditions requires juxtaposition. Proceedings of the National Academy of Sciences. 101(48): 16917-16922.

EVEN, S., CHARLIER, C., NOUAILLE, S., ZAKOUR, NLB., CRETENET, M., COUSIN, FJ., LE LOIR, Y. 2009.Staphylococcus aureus virulence expression is impaired by Lactococcus lactis in mixed cultures. Applied and environmental microbiology. 75(13): 4459-4472.http://dx.doi.org/10.1128/AEM.02388-08

FEDERLE, MJ., BASSLER, BL. 2003. Interspecies communication in bacteria.Journal of Clinical Investigation. 112(9): 12911299.http://dx.doi.org/10.1172/JCI20195

FOSTER, KR. 2005. Hamiltonian medicine: why the social lives of pathogens matter. Science. 308(5726):

1270.http://dx.doi.org/10.1126/science. 1108158

FRICK, T., SCHUSTER, S. 2003. An example of the prisoner's dilemma in biochemistry. Naturwissenschaften. 90(7):

331.http://dx.doi.org/10.1007/s00114-003-0434-3

GENTRY, TJ., WICKHAM, GS., SCHADT, CW., HE, Z., ZHOU, J. 2006.

Microarray applications in microbial ecology research. Microbial Ecology. 52(2) 159-175.http://dx.doi.org/10.1007/s00248-006-9072-6

GORE, J., YOUK, H., VAN OUDENAARDEN, A. 2009. Snowdrift game dynamics and facultative cheating in yeast. Nature.459(7244): 253 256.http://dx.doi.org/10.1038/nature07921

HANSEN, SK., RAINEY, PB., HAAGENSEN, J., MOLIN, S. 2007. Evolution of species interactions in a biofilm community. Nature. 445(7127): 533 536.http://dx.doi.org/10.1038/nature05514

HE, Z., GENTRY, TJ., SCHADT, CW., WU, L., LIEBICH, J., CHONG, SC. ZHOU, J. 2007. GeoChip: a comprehensive microarray for investigating biogeochemical, ecological and environmental processes. The ISME Journal .1(1): 67-77.http://dx.doi.org/10.1038/ismej.2007.2

HIBBING, ME., FUQUA, C., PARSEK, MR., PETERSON, SB. 2009. Bacterial competition: surviving and thriving in the microbial jungle. Nature Reviews Microbiology. 8(1): 15-25.http://dx.doi.org/10.1038/nrmicro2259

HILLESLAND, KL., STAHL, DA. 2010. Rapid evolution of stability and productivity at the origin of a microbial mutualism. Proceedings of the National Academy of Sciences. 107(5): 2124-2129.

HOGAN, DA., VIK, Å., KOLTER, R. 2004. A Pseudomonas aeruginosa quorum- sensing molecule influences Candida albicans morphology. Molecular microbiology. 54(5):1212-1223.http://dx.doi.org/10.1111/i.13652958.2004.04349.x 
HORNBY, JM., JENSEN, EC., LISEC, AD., TASTO, JJ., JAHNKE, B. SHOEMAKERM R., NICKERSON, KW. 2001. Quorum sensing in the dimorphic fungus Candida albicans is mediated by farnesol. Applied and Environmental Microbiology. 67(7):

2992.http://dx.doi.org/10.1128/AEM.67.7.2982-2992.2001

JOHNSON, L., HORSMAN, SR., CHARRON-MAZENOD, L., TURNBULL, AL., MULCAHY, H., SURETTE, MG., LEWENZA, S. 2013. Extracellular DNA-induced antimicrobial peptide resistance in Salmonella enterica serovar Typhimurium. BMC microbiology. 13(1): 115.http://dx.doi.org/10.1186/14712180-13-115

KELLER, L., SURETTE, MG. 2006. Communication in bacteria: an ecological and evolutionary perspective. Nature Reviews Microbiology. 4(4): 249258.http://dx.doi.org/10.1038/nrmicro1383

KIM, HJ., BOEDICKER, JQ., CHOI, JW., ISMAGILOV, RF. 2008. Defined spatial structure stabilizes a synthetic multispecies bacterial community.Proceedings of the National Academy of Sciences. 105(47): 1818818193.

KREFT, JU. 2004. Biofilms promote altruism. Microbiology. 150(8): 27512760.http://dx.doi.org/10.1099/mic.0.26829-0

LAROSSA, R., KUNER, J., HAGEN, D., MANOIL, C., KAISER, D. 1983. Developmental cell interactions of Myxococcus xanthus: analysis of mutants. Journal of bacteriology. 153(3): 1394-1404.

LEDFORD, H. 2008. The death of microarrays? Nature. 455(7215): 847.http://dx.doi.org/10.1038/455847a

MACLEAN. RC., GUDELJ, I. 2006. Resource competition and social conflict in experimental populations of yeast. Nature 441(7092): 498 501.http://dx.doi.org/10.1038/nature04624

MAGNUSON, R., SOLOMON, J., GROSSMAN, AD. 1994. Biochemical and genetic characterization of a competence pheromone from B. subtilis. Cell. 77(2): 207-216.http://dx.doi.org/10.1016/0092-8674(94)90313-1

MILLER, MB., BASSLER, BL. 2001. Quorum sensing in bacteria. Annual Reviews in Microbiology. 55(1):

$165-$

199.http://dx.doi.org/10.1146/annurev.micro.55.1.165

MITRI, S., XAVIER, JB., FOSTER, KR. 2011. Social evolution in multispecies biofilms. Proceedings of the National Academy of Sciences. 108(Supplement 2): 10839-10846.

MOONS, P., VAN HOUDT, R., AERTSEN, A., VANOIRBEEK, K., ENGELBORGHS, Y., MICHIELS, CW. 2006. Role of quorum sensing and antimicrobial component production by Serratia plymuthica in formation of biofilms, including mixed biofilms with Escherichia coli. Applied and environmental

$7294-$

NOVAK, M., PFEIFFER, T., LENSKI, RE., SAUER, U., BONHOEFFER, S. 2006. Experimental Tests for an Evolutionary Trade- Off between Growth Rate and Yield in E. coli. The American Naturalist. 168(2): 242 251.http://dx.doi.org/10.1086/506527

O'LOUGHLIN, CT., MILLER, LC., SIRYAPORN, A., DRESCHER, K. SEMMELHACK, MF., BASSLER, BL. 2013. A quorum-sensing inhibitor blocks Pseudomonas aeruginosa virulence and biofilm formation. Proceedings of the National Academy of Sciences. 110(44): 7981-17986.

PARSEK, MR., GREENBERG, EP. 2005. Sociomicrobiology: the connections between quorum sensing and biofilms. Trends in microbiology. 13(1): 2733.http://dx.doi.org/10.1016/j.tim.2004.11.007

PELZ, O., TESAR, M., WITTICH, RM., MOORE, ER., TIMMIS, KN., ABRAHAM, WR. 1999. Towards elucidation of microbial community metabolic pathways: unravelling the network of carbon sharing in a pollutant- degrading bacterial consortium by immunocapture and isotopic ratio mass spectrometry. Environmental microbiology. 1(2): 167-174.http://dx.doi.org/10.1046/j.14622920.1999.00023.x

PETTIT, RK. 2009. Mixed fermentation for natural product drug discovery. Applied microbiology and biotechnology. 83(1): 19 25.http://dx.doi.org/10.1007/s00253-009-1916-9

PFEIFFER, T., BONHOEFFER, S. 2004. Evolution of Cross- Feeding in Microbial Populations. The American naturalist. 163(6): E126E135.http://dx.doi.org/10.1086/383593

PFEIFFER, T., SCHUSTER, S. 2005. Game-theoretical approaches to studying the evolution of biochemical systems. Trends in biochemical sciences. 30(1): 2025.http://dx.doi.org/10.1016/j.tibs.2004.11.006

PFEIFFER, T., SCHUSTER, S., BONHOEFFER, S. 2001. Cooperation and competition in the evolution of ATP-producing pathways. Science. 292(5516): 504-507.http://dx.doi.org/10.1126/science.1058079

RAINEY, PB., RAINEY, K. 2003. Evolution of cooperation and conflict in experimental bacterial populations. Nature. 425(6953): 74.http://dx.doi.org/10.1038/nature01906

RAJILIĆ-STOJANOVIĆ, M., BIAGI, E., HEILIG, HG., KAJANDER, K., KEKKONEN, RA., TIMS, S., DE VOS. WM. 2011. Global and deep molecular analysis of microbiota signatures in fecal samples from patients with irritable bowel syndrome. Gastroenterology. 141(5): 1801.http://dx.doi.org/10.1053/j.gastro.2011.07.043
RATNIEKS, FL., FOSTER, KR., WENSELEERS, T. 2006. Conflict resolution in insect societies. Annu. Rev. Entomol. 51: 581608.http://dx.doi.org/10.1146/annurev.ento.51.110104.151003

ROH, SW., ABELL, GC., KIM, KH., NAM, YD., BAE, JW. 2010. Comparing microarrays and next-generation sequencing technologies for microbial ecology research. Trends in biotechnology. 28(6):

299.http://dx.doi.org/10.1016/j.tibtech.2010.03.001

ROZEN, DE., PHILIPPE, N., ARJAN DE VISSER, J., LENSKI, RE. SCHNEIDER, D. 2009. Death and cannibalism in a seasonal environment facilitate bacterial coexistence. Ecology letters. 12(1): 34 44.http://dx.doi.org/10.1111/j.1461-0248.2008.01257.x

RUTHERFORD, ST., BASSLER, BL. 2012. Bacterial quorum sensing: its role in virulence and possibilities for its control. Cold Spring Harbor perspectives in medicine. 2(11)

SANDOZ, KM., MITZIMBERG, SM., SCHUSTER, M. 2007. Social cheating in Pseudomonas aeruginosa quorum sensing. Proceedings of the National Academy of Sciences. 104(40): 15876-15881.

SCHELIN, J., WALLIN-CARLQUIST, N., COHN, MT., LINDQVIST, R., BARKER, GC. 2011. The formation of Staphylococcus aureus enterotoxin in food environments and advances in risk assessment. Virulence. 2(6): 580592.http://dx.doi.org/10.4161/viru.2.6.18122

SCHENA, M., SHALON, D., DAVIS, RW., BROWN, PO. 1995. Quantitative monitoring of gene expression patterns with a complementary DNA microarray. Science. 270(5235): 467-470.http://dx.doi.org/10.1126/science.270.5235.467

SCHINK, B. 2002. Synergistic interactions in the microbial world. Antonie Van Leeuwenhoek. 81(1-4): 257-261.http://dx.doi.org/10.1023/A:1020579004534

SCHJØRRING, S., KOELLA, JC. 2003. Sub-lethal effects of pathogens can lead to the evolution of lower virulence in multiple infections. Proceedings of the Royal Society of London. Series B: Biological Sciences. 270(1511): 189-193.

SEBAT, JL., COLWELL, FS., CRAWFORD, RL. 2003. Metagenomic profiling: microarray analysis of an environmental genomic library. Applied and environmental microbiology. 69(8):

4934.http://dx.doi.org/10.1128/AEM.69.8.4927-4934.2003

SEITZ, P., BLOKESCH, M. 2013. DNA-uptake machinery of naturally competent Vibrio cholerae. Proceedings of the National Academy of Sciences. 110(44): 17987-17992.http://dx.doi.org/10.1073/pnas.1315647110

SHOU. W., RAM, S., VILAR, JM. 2007. Synthetic cooperation in engineered yeast populations. Proceedings of the National Academy of Sciences. 104(6): $1877-1882$

SOLOMON, JM., LAZAZZERA, BA, GROSSMAN, AD 1996. Purification and characterization of an extracellular peptide factor that affects two different developmental pathways in Bacillus subtilis. Genes and development. 10(16): 2014-2024.http://dx.doi.org/10.1101/gad.10.16.2014

SOLOMON, JM., MAGNUSON, R., SRIVASTAVA, A., GROSSMAN, AD. 1995. Convergent sensing pathways mediate response to two extracellular competence factors in Bacillus subtilis. Genes and development. 9(5): 547558.http://dx.doi.org/10.1101/gad.9.5.547

STEINER, E., SCOTT, J., MINTON, NP., WINZER, K. 2012. An agr quorum sensing system that regulates granulose formation and sporulation in Clostridium acetobutylicum. Applied and environmental microbiology. 78(4): 11131122.http://dx.doi.org/10.1128/AEM.06376-11

STREIT, WR., SCHMITZ, RA. 2004. Metagenomics-the key to the uncultured microbes. Current Opinion in Microbiology. 7(5): 492 498.http://dx.doi.org/10.1016/j.mib.2004.08.002

SUCKOW, G., SEITZ, P., BLOKESCH, M. 2011. Quorum sensing contributes to natural transformation of Vibrio cholerae in a species-specific manner. Journal of bacteriology. 193(18): 4914-4924.http://dx.doi.org/10.1128/JB.05396-11

SZÉKELY, T., MOORE, AJ., KOMDEUR, J. (Eds) 2010. Social behaviour: genes, ecology and evolution. Cambridge University Press.

THOENDEL, M., KAVANAUGH, JS., FLACK, CE., HORSWILL, AR. 2011. Peptide signaling in the Staphylococci. Chemical reviews.111(1): 117151.http://dx.doi.org/10.1021/cr100370n

THOMAS, MB., WATSON, EL., VALVERDE- GARCIA, P. 2003. Mixed infections and insect-pathogen interactions. Ecology Letters. 6(3): 183 188.http://dx.doi.org/10.1046/j.1461-0248.2003.00414.x

TIRUMALAI, PS., PRAKASH, S. 2012a. Expression of virulence genes by Listeria monocytogenes J0161 in natural environment. Brazilian Journal of Microbiology. 43(2): 83822012000200050

TIRUMALAI, PS., PRAKASH, S. 2012b. Antibiotic Resistance in Co-Culture Biofilm of Listeria monocytogenes J0161. American Journal of Microbiology. 3(1): 7.http://dx.doi.org/10.3844/ajmsp.2012.7.17

TOTTEY, W., DENONFOUX, J., JAZIRI, F., PARISOT, N., MISSAOUI, M., HILL, D., BRUGËRE, JF. 2013. The Human Gut Chip "HuGChip", an Explorative Phylogenetic Microarray for Determining Gut Microbiome Diversity at Family Level. PloS one. 8(5): e62544.http://dx.doi.org/10.1371/journal.pone.0062544

VAN NOSTRAND, JD., WU, WM., WU, L., DENG, Y., CARLEY, J., CARROLL, S., ZHOU, J. 2009. GeoChip- based analysis of functional microbial communities during the reoxidation of a bioreduced uranium- 
contaminated aquifer. Environmental Microbiology. 11(10): 26112626.http://dx.doi.org/10.1111/j.1462-2920.2009.01986.x

VELICER, GJ. 2003. Social strife in the microbial world. TRENDS in Microbiology. 11(7): 330-337.http://dx.doi.org/10.1016/S0966-842X(03)00152-5 VERWEIJ-VAN VUGHT, AMJJ., NAMAVAR, F., VEL, WAC., SPARRIUS, M., MACLAREN, DM. 1986. Pathogenic synergy between Escherichia coli and Bacteroides fragilis or B. vulgatus in experimental infections: a non-specific phenomenon. Journal of medical microbiology.21(1): 43 47.http://dx.doi.org/10.1099/00222615-21-1-43

VOJVODIC, S., BOOMSMA, JJ., EILENBERG, J., JENSEN, AB. 2012. Virulence of mixed fungal infections in honey bee brood. Frontiers in zoology. 9(5):1-5.

WANG, F., ZHOU, H., MENG, J., PENG, X., JIANG, L., SUN, P., XIAO, X. 2009. GeoChip-based analysis of metabolic diversity of microbial communities at the Juan de Fuca Ridge hydrothermal vent. Proceedings of the National Academy of Sciences. 106(12): 4840-4845.http://dx.doi.org/10.1073/pnas.0810418106

WATERS, CM., LU, W., RABINOWITZ, JD., BASSLER, BL. 2008. Quorum sensing controls biofilm formation in Vibrio cholerae through modulation of cyclic di-GMP levels and repression of vpsT. Journal of bacteriology. 190(7): 2527-2536.http://dx.doi.org/10.1128/JB.01756-07

WINTERMUTE, EH., SILVER, PA. 2010a. Dynamics in the mixed microbial concourse. Genes and development. 24(23): 26032614.http://dx.doi.org/10.1101/gad.1985210

WINTERMUTE, EH., SILVER, PA. 2010b. Emergent cooperation in microbial metabolism. Molecular systems biology. 6(1).

WU, L., THOMPSON, DK., LI, G., HURT, RA., TIEDJE, JM., ZHOU, J. 2001 Development and evaluation of functional gene arrays for detection of selected genes in the environment. Applied and environmental microbiology. 67(12) 5780-5790.http://dx.doi.org/10.1128/AEM.67.12.5780-5790.2001

XAVIER, KB., BASSLER, BL. 2005. Interference with AI-2-mediated bacterial cell-cell communication. Nature. 437(7059): 750753.http://dx.doi.org/10.1038/nature03960

ZHOU, J. 2003. Microarrays for bacterial detection and microbial community analysis. Current opinion in Microbiology. 6(3): 288 294.http://dx.doi.org/10.1016/S1369-5274(03)00052-3

ZIMMER, C. 2009. Microcosm: E-coli and the New Science of Life. Random House.http://dx.doi.org/10.1126\%2Fscience.277.5331.1453 